\title{
APR 11968
}

$$
\text { GEAP-5595 }
$$

AEC RESEARCH AND

DEVELOPMENT REPORT

FEBRUARY 1968

\section{SOUTHWEST EXPERIMENTAL FAST OXIDE REACTOR DEVELOPMENT PROGRAM FIFTEENTH QUARTERLY REPORT NOVEMBER 1967-JANUARY 1968}

U.S. ATOMIC ENERGY COMMISSION

CONTRACT AT (04-3)-540

ADVANCED PRODUCTS OPERATIOH

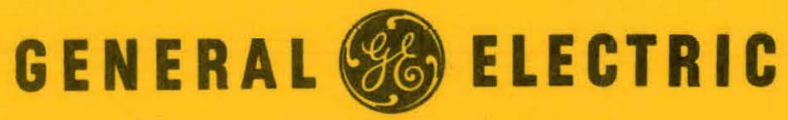




\section{DISCLAIMER}

This report was prepared as an account of work sponsored by an agency of the United States Government. Neither the United States Government nor any agency Thereof, nor any of their employees, makes any warranty, express or implied, or assumes any legal liability or responsibility for the accuracy, completeness, or usefulness of any information, apparatus, product, or process disclosed, or represents that its use would not infringe privately owned rights. Reference herein to any specific commercial product, process, or service by trade name, trademark, manufacturer, or otherwise does not necessarily constitute or imply its endorsement, recommendation, or favoring by the United States Government or any agency thereof. The views and opinions of authors expressed herein do not necessarily state or reflect those of the United States Government or any agency thereof. 


\section{DISCLAIMER}

Portions of this document may be illegible in electronic image products. Images are produced from the best available original document. 


\section{SOUTHWEST EXPERIMENTAL FAST OXIDE \\ REACTOR DEVELOPMENT PROGRAM}

Fifteenth Quarterly Report

November 1967 -January 1968

Compiled by:

G. R. Pflafterer, Development Project Engineer SEFOR Research and Development

Approved by: B. Wo/fe/kMt.

Bertram Wolfe, Manager

Plant Engineering and Projects

Prepared for the

Southwcot Atomic Encrey Aooocintco for transmittal to the United States Atomic Energy Commission under

Contract Number AT(04-3) -540

Printed in U.S.A. Available from the Clearing House for Federal Sciextific and Tecbnical Information National Bureau of Standards, U.S. Bepartmedt of Commerce Springlield, Virginio Price: 83.00 per copy 


\section{LEGAL NOTICE}

This report was prepared as an account of Government sponsored work. Neitber the United States, nor the Commission, nor any person acting on behalf of the Commission:

A. Makes any warranty or representation, expressed or implied, with respect to the accuracy, completeness, or usefulness of the information contained in this report, or that the use of any information, apparatus, method, or process disclosed in this report may not infringe privately owned rights; or

B. Assumes any liabilities with respect to the use of, or for damages resulting from the use of any information, apparatus, method, or process disclosed in this report.

As used in the above, "person acting on behalf of the Commission" includes any employee or contractor of the Commissinn, or employee of such contractor, to the extent that such employee or contractor of the Commission, or employee of such contractor prepares, disseminates, or provides access to, any information pursuant to bis employment or contract with the Commission, or bis employment with such contractor. 


\section{TABLE OF CONTENTS}

$\begin{array}{ll}\text { ABSTRACT } \\ \text { SECTION I } & \text { INTRODUCTION } \\ \text { SECTION II } & \text { SUMMARY } \\ & 2.1 \quad \text { Completed Tasks } \\ & 2.2 \quad \text { Task 1-Planning the Experimental Program } \\ 2.3 & \text { Task 4-Special Instrumentation } \\ 2.4 & \text { Task 6-Reactivity Controls Required for Experimentation } \\ 2.5 & \text { Fuel Fabrication } \\ 2.6 & \text { Startup Testing } \\ 2.7 & \text { SEFOR Training } \\ 2.8 & \text { Plant Construction }\end{array}$

Page

SECTION III

TASK 1-PLANNING THE EXPERIMENTAL PROGRAM

3.1 Task 1.2-Final Specification of the Experimental Program 5

SECTION IV

TASK 4-SPECIAL INSTRUMENTATION

4.1 Task 4.2-Core Flux Detector System

SECTION V

TASK 6-REACTIVITY CONTROLS REQUIRED FOR EXPERIMENTS 6

5.1 Task 6.1-Fast Reactivity Excursion Device (FRED) 6

5.2 TAßIK 6.2-Oocillator Drive

SECTION VI

TASK 9-FUEL FABRICATION

8

6.1 Purpose

8

6.2 Past Accomplishments $\quad$.

6.3 Current Results 8

SECTION VII

TASK 10-STARTUP TESTING

7.1 Task 10.3-Wet Critical Testing 13

SECTION VIII SEFOR TRAINING $\quad$ S 14

8.1 Purpose 14

8.2 Past Accomplishments $\quad 14$

8.3 Current Results $\quad 14$

SECTION IX $\quad$ PLANT CONSTRUCTION 14

9.1 Mechanical Department 14

9.2 Electrical Department . 15

9.3 Construction Management . 15

CONTRIBUTORS 16

$\begin{array}{ll}\text { DISTRIBUTTION } & 17\end{array}$ 


\section{ABSTRACT}

This report summarizes the work performed on the Research and Development Program for the Southwest Experimental Fast Oxide Reactor during the period from
November 1, 1967 through January 31, 1968

The work was performed under contract AT(04-3)-540 with the United States Atomic Energy Commission.

\section{SECTION I}

\section{INTRODUCTION}

SE FOR (Southwest Experimental Fast Oxide Reactor) is a 20 MWt fast, sodiumcooled reactor with characteristics similar to the large, soft spectrum fast breeder reactors fueled with mixed $\mathrm{PuO}_{2}-\mathrm{U}-238 \mathrm{O}_{2}$, for which studies indicate the potential for producing low cost power. SEFOR will be used to obtain physics and engineering data at fuel compositions, temperatures, and crystalline states characteristic of power reactor operating conditions. SEFOR is particularly designed for the systematic determination of the Doppler coefficient of reactivity at temperatures up to the vicinity of fuel melting.

The SEFOR project consists of two major parts: the design and construction of the reactor facility and the related research and development program. Funds for the design and construction of the facility are being provided by the Southwest Atomic Energy Associates (a group of 17 investorowned utility companies located in the south and southwest of the United States), together with the Karlsruhe Laboratory of The Federal Republic of Germany, Euratom, and the General Electric Company.

The United States Atomic Energy Commission is supporting the research and development program. The $\mathrm{R}$ and $\mathrm{D}$ program consists of two phases:

Phase I-Preoperational research and development,
Phase II-The reactor test program after the start of reactor operation.

Phase I consists of 10 major tasks divided into 28 subtasks. This report summarizes the tasks scheduled for activity at this time. The remaining tasks will be included in future reports as the work progresses.

The following periodic reports have been issued in partial fulfillment of United States Atomic Energy Commission Contract AT(04-3) -540 .

1. "Southwest Experimental Fast Oxide Reactor Development Program, First Quarterly. Report, April - June 1964," GEAP-4594 (July 1964).

2. "Southwest Experimental Fast Oxide Reactor Develnpment Program, Second Quarterly Report, July September 1964," GEAP-4742 (October 1964).

3. "Southwest Experimental Fast Oxide Reactor Development Program, Third Quarterly Report, October 1964 January 1965," GEAP-4799 (February 1965).

4. "Southwest Experimental Fast Oxide Reactor Development Program, Fourth Quarterly Rcport, February = April 1965," GEAP-4864 (May 1965). 
5. "Southwest Experimental Fast Oxide Reactor Development Program, Fifth Quarterly Report, May - July 1965," GEAP-4934 (August 1965).

6.- "Southwest Experimental Fast Oxide Reactor Development Program, Sixth Quarterly Report, August - October 1965," GEAP-4994 (November 1965).

7. "Southwest Experimental Fast Oxide Reactor Development Program, Seventh Quarterly Report, November 1965 January 1966," GEAP-5108 (February 1966).

8. "Southwest Experimental Fast Oxide Reactor Development Program, Eighth Quarterly Report, February - April 1966," GEAP-5160 (May 1966).

9. "Southwest Experimental Fast Oxide Reactor Development Program, Ninth Quarterly Report, May - July 1966," GEAP-5208 (August 1966)

10. "Southwest Experimental Fast Oxide Reactor Development Program, 'Tenth Quarterly Report, August - October 1966," GEAP-5301 (November 1967).

11. "Southwest Experimental Fast Oxide Reactor Development Program, Eleventh Quarterly Report, Novemuer 1960 January 1967," GEAP-5442 (February 1987).

12. "Southwest Experimental F'ast Oxide Reactor Development Program, Twelfth Quarterly Report, February - April 1967," GEAP-5498 (May 1967).

13. "Southwest Experimental Fast Oxide Reactor Development Program, Thirteenth Quarterly Report, May - July 1967," GEAP-5533 (August 1967).

14. "Southwest Experimental Fast Oxide Reactor Development Program, Fourteenth Quarterly Report, August-October 1967," GEAP-5561 (November 1967).
In addition, the following topical reports have been issued:

1. Novak, P. E., and Asamoto, R: R., "A Survey for a High Temperature Sensor for SEFOR," GEAP-4903 (July 1965).

2. Quinn, E. P., "Vibration of SEFOR Fuel Rods in Parallel Flow," GEAP4966 (September 1965).

3. Johnson, M. L., "A Description of Fuel and Other Core Materials Procured for SEFOR Critical Experiments in ZPR-III," GEAP-5133 (December 1965).

4. Protsik, R., "Epithermal Cápture and Fission Distribution in a Fuel Rod - The Computer Code REAX," GEAP-4973 (April 1966).

5. Novak, P. E., and Asamoto, R. R., "An Out-of-Pile Evaluation of W-Re Thermocouple Systems for Use to ' $4700^{\circ} \mathrm{F}$ in Mixed Oxide," GEAP5166 (May 1966)

6. Pflasterer, G. R., "SEFOR Experimental Program Planning, Vols. I and II," GEAP-5092 (August 1966).

7. Morrell, R. P., "SEFOR $\beta / \ell$ Measurements bỹ Nolse Alualysis Techniques," IDO-17210 (August 1966).

8. Williams, R. F., and Polomik, E. E., "Pressure Drop and Dye Tests with Water on the SEFOR Prototype Fuel Bundle," GEAP-5129 (February 1966).

9. Craig, C. N., Ryer, C. M., and Thompson, M. L., "PlutoniumUranium Mixed Oxide Fuel Pellet Fabrication Development for the Suuthwest Experimental Fast Oxide Reactor," GEAP-5285 (October 1966).

10. Polomik, E. E., and Williams, R. F., "Coolant Surface Turbulence Study, SEFOR Reactor Vessel," GEAP6008 (Docember 1966). 
11. Wilkinson, L., "Use of Neutron Filters for Fast Reactor Fuel Irradiations in a Thermal Core," GEAP-5035 (April 1967).

12. Wilkins, L., et al., "'Devices for Cyclic and Transient Power Control in a Steady-State Neutron Flux Gradient," GEAP-5036 (May 1967).

13. Reynolds, A. B., and Stewart, S. L., "Analysis of the SEFOR Mockup Critical Experiments in ZPR-3," GEAP-5294 (March 1967).

14. Wilkinson, D., "Weighted Doppler Analysis Code-WEDOP, " GEAP5513 (October 1967).

15. Craig, E. R., Fulton, R. H., Damon, J. J., "Design and Testing of Solenoid and. Instrument Lead Connector for Use in SEFOR Reactor Vessel," GEAP-5307 (March 1967).
16. Asamoto, R. R., Perry, K. J., and Zebroski, E. L., "The Effective and Diametral Thermal Expansion of $\mathrm{UO}_{2}$ Under a Radial Temperature Gradient," GEAP-5284 (October 1966).

17. McVean, R. L., Weitzberg, A., Kremser, J. A., Leridon, A. M., and Long, J. K., "Critical Studies of the Southwest Experimental Fast Oxide Reactor (SEFOR) in ZPR-3, " ANL-7248.

18. Polomik, E., "Fluid Flow and Vibration Tests, $1 / 2$-Scale Model of SEFOR Reactor Vessel," GEAP-5440 (April 1967): :

19. Field, J.H., Johnson, M.L., and Novak, P.E., "An Evaluation of the Effect of Design and Operating Variables on SEFOR Fuel and Fuel Cladding," GEAP-5309 (December 1967).

\subsection{COMPLETED TASKS}

Experimental and/or analytical work has been completed on the lasks listed bclow, although in some cases work on topical reports is continuing:

\section{TASK}

1.1

2.0

3.1

3.2

4.1 .

4.3

\section{$\underline{\text { TITLE }}$}

Specifications for the Reactor and Experimental Program

Experimental Program in ZPR-III

Fuel Cladding Transient Performance, 5.6

Specification of Fuel Composition

Fuel Temperature Measurement

Faileá Fuel Loc:ation $\underline{\text { TASK }}$

4.4

4.5

5.1

5.2

5.3

5.4

5.5

7.0

8.1

8.2
TITLE

Instrument Lead Connectors

Speclal Inslrumentation

Core Mockup and Heated Fuel Test

Hydraulic Flow Tests-Vessel

Hydraulic Flow Tests-Fuel Rods

Sodium Performance Tests

Thermal Shock

Sodium Heat Transfer Tests

Fuel Handling.

Nuclear Analysis

Nuclear Design 


\subsection{TASK 1-PLANNING THE EXPERIMENTAL PROGRAM}

The primary effort of Task 1.2 has been completed and the final report was typed, which describes the detailed test program specifications. Work was initiated on a plan for nondestructive (in the SEFOR refueling cell) and destructive (off the SEFOR site) irradiated fuel examination during the test program.

\subsection{TASK 4-SPECIAL INSTRUMENTATION}

Detail design was initiated on support fixtures to hold the neutron detectors in position outside the core. Assembly of both fission and gamma chambers was started.

\subsection{TASK 6-REACTIVITY CONTROLS REQUIRED FOR EXPERIMENTATION}

A series of FRED tests was carried out with a new method of lift-off indication. The poison rod material compatibility tests were completed and indicate the use of Type 304 stainlces steel with boron carbide will be satisfactory. The oscillator mechanism modifications were completed.

\subsection{FUEL FABRICATION}

Luading and wclding of fuel rods ceased on January 9, 1968, pending resolution of the total gas contents of the fuel pellets. Nuclcar Fuel Services (NFS) measurements show that the fuel pellets meet the specification in all respects, while independent laboratory tests have shown that the total gas content (exc.luding moisture) is approximately a factor of 1.5 higher than the specification limit.

One-hundred-four rods were shipped to SEFOR and inspected there.

The fuel channels were received at the SEFOR site. Fabrication of the other core hardware continued with no significant stoppage in schedule, although several fabrication problems were encountered.

Fabrication continued on the instrumented fuel assemblies with some schedule slippage caused by fabrication problems and vendor delays.

\subsection{STARTUP TESTING}

Tests were performed which indicated that the SEFOR transient amplifiers would be satisfactory for the planned reactor noise measurements. The reactor vessel surveillance specimens were received.

\subsection{SEFOR TRAINING}

The formalized portion of the SEFOR training program in California was completed and all personnel transferred to the SEFOR site.

\subsection{PLANT CONSTRUCTION}

The release for construction of the electrical system wiring drawings was completed during this quarter with the exception of several miscellaneous detail drawings.

The general work contractor returned to the site on December 18, 1967 and completed the closure of the refueling cell construction opening.

The insulation work in the field progressed on schedule.

The piping contractor completed the installation of the MCS and ACS sodium piping systems. The contractor expects to complete the installation of all sodium piping within the next month. 


\subsection{TASK 1.2-FINAL SPECIFICATION OF THE EXPERIMENTAL PROGRAM}

\section{1 .1 Purpose}

The purpose of Task 1.2 is to provide a detailed specification of the experimental program. This will include the planning of the number and sequence of tests, the specification of reactor conditions (power, temperature, flow, etc.), and the preparation of procedures for data reduction and interpretation. In addition, the specifications of the reactor equipment prepared under Task 1.1 will be reviewed as required to take into account results from the detailed design of equipment and from the preoperational research and development program.

\subsubsection{Past Accomplishments}

A reactivity feedback model for use in the analysis of experimental data and procedures for use of static, oscillator, and transient data to determine the Doppler coefficient defined by the model were outlined. An outline of the SEFOR experimental program for Core I was completed. Three computer codes for the analysis of SEFOR oscillator test data have been specified.

The primary effort of task 1.2 has been completed and the final report was typed and reviewed. As the quarter closed; corrections to the final report were being made prior to submission for publication.

\subsubsection{Current Results}

Work was begun on a plan for nondestructive and destructive examination of irradiated fuel to be performed during the test program. It is intended to provide a detailed plan for use of the 18 "guinea pig" rods which are to be fabricated with $25 \%$ $\mathrm{PU}$ enrichment (compared with $18.7 \% \mathrm{Pu}$ enrichment in the normal fuel). A total of 12 fuel rod positions at two radial core locations are accessible via six through-head refueling parts in the vessel head. It is planned to load both guinea pig rods and normal fuel rods into these locations to provide convenient access for fuel examination both in-cell and at a "hot laboratory" equipped for destructive examination.

\section{SECTION IV}

\section{TASK 4-SPECIAL INSTRUMENTATION}

\subsection{TASK 4.2-CORE FLUX DETECTOR SYSTEM}

\subsubsection{Purpose}

The objeclives of Tagk 1.2 are to develop and supply a suitable detector sys- tem for recording the transient flux during the SEFOR Experimental Program. The data will be used to determine the total power and energy generated and the net reactivity as a function of lime during the traneient. 


\subsubsection{Past Accomplishments}

Several detectors and detector concepts were examined. Final system configuration was selected after completion of tests on prototype detectors and amplifiers. The final system selected uses logarithmic amplifiers with a compensated fission chamber covering the low dccades of power and a gamma chamber covering the higher ranges of power. In the largest planned transients, the overall transient will be covered by overlaying the results of the two detector-amplifier systems. The system concept has been tested using prototype equipment on transient pulses at Super Kukla.

\subsubsection{Current Accomplishments}

During the period detail design was initiated on shielding and transporter equipment for the neutron detectors; three of which will be located at core height in guide tubes located in the radial biological shield- ing beyond the reflector region. Detail design of the shielding and transporter equipment is now $80 \%$ complete and procurement of parts is underway. The design situates the detector in a lead-filled capsule which will move on spring loaded slides within the curved 5 -inch-diameter guide tubes. Positioning will be accomplished by pushing each assembly up its own guide tube from the reflector drive room below the reactor cavity using a hollow, three-sectioned, hinged pole some 16 feet in length. Detectorsignal cables will be carried inside the push pole.

A shield plug with center hole accommodating the push pole will block neutron streaming in each of the three guide tubes to prevent activation of equipment below.

The GE Sensor Shop has begun assembly of both the U-238 fission chambers and the gamma chambers.

\section{SECTION V}

\section{TASK 6-REACTIVITY CONTROLS REQUIRED FOR EXPERIMENTATION}

\subsection{TASK 6.1-FAST REACTIVITY FXCURSION DEVICE (FRED)}

\subsubsection{Purpose}

The FRED is being developed to initiate reactor power excursions under controlled conditions. The device developed under this task will be used in SEFOR to carry out the planned excursinns during the experimental progräm.

\subsubsection{Past Accomplishments}

The FRED I model test program was completed and a detailed analysis of the reactor model was carried out. The detailed design and fabrication of the positioner device was completed. Plans were developed to test the reactor model under heated conditions.

\subsubsection{Test Program}

The test model No. 1 was modified for a new lift-off switch design and a position sensor. These were both installed in the test model and several tests carried out to check their basic characteristics before including them in the reactor model design. ' $\mathrm{l}$ 'he results of the test indicate that both of these performed satisfactorily. The lift-off switch indicates when the piston has broken contact between two contact points. The variable reluctance device is an analog signal to indicate the relative motion of the FRED before and after actuation of the lift-off switch. 


\subsubsection{Poison Rod Design}

Preliminary tests to determine the compatibility of boron carbide and Types $304,430 \mathrm{~F}$, and 446 stainless steels have been completed. The tests were carried out in $1600^{\circ} \mathrm{F}$ for periods of 100 and 400 hours. The test specimens have been metallographically prepared and examined. The compatibility samples consisted of rods of each type of stainless steel with a hole drilled down the center for the $\mathrm{B}_{4} \mathrm{C}$ powder. After loading, each capsule was placed in a Vycor tube, evacuated, back-filled with argon, and sealed. The capsules were placed in a furnace and the temperature slowly raised to $1600^{\circ} \mathrm{F}$ and maintained for a period of 400 hours. The first group of samples were withdrawn from the furnace at the end of the 100-hour period. The results of the metallographic examinations of these samples indicate an observed reaction depth of 0.004 inch after 100 hours, and 0.10 inch after 400 hours in the Type 304 stainless steel. The Types $430 \mathrm{~F}$ and 446 stainless steels were attacked to a lesser degree. The primary conclusion as a result of these tests indicate that Type 304 stainless steel with boron carbide poison can be used for the FRED poison slugs as well as the oscillator poison slug. Since the wall thickness is over 0.060 the effect of losing 0.010 off this wall thickness will not affect the performance of the poison silugis.

In addition to the above-mentioned samples some tests were carried out with a copper diffusion harrier between the $\mathrm{B}_{4} \mathrm{C}$ and steel; the results of these tests were inconclusive as the copper was very porous. The copper barrier may be used in the FRED poison slugs for added margin.

\subsubsection{FRED Design}

The dctail fabrication drawings for the. FRED Reactor Model have been completed and are presently being checked before being released for quotations for fabrication.

\subsection{TASK 6.2-OSCILLATOR DRIVE}

\subsubsection{Purpose}

The purpose of this task is to develop a device for introducing oscillating increments of reactivity into the core. The results of tests will give information relative to the design requirements, including plant dynamic response and full-power reactivity (temperature) coefficient.

\section{2,2 Past Accomplishments}

The oscillator mechanism room temperature tests have been completed. The positioner drive fabrication has been completed. Procurement of components for the balanced oscillator control system has been completed and fabrication started.

\subsubsection{Oscillator Mechanis ms}

The oscillator mechanism was dismantled during the past quarter and has been further disassembled, cleaned, lubricated, and reassembly started during this quarter. The modifications as reported earlier have all been made and a checkout test series will be carried out later when the positioner mechanism is being tested.

\subsubsection{Balanced Oscillator System}

All components for the manual oscillator control system have been received by NEBS, and fabrication assembly of the components has started. It is expected that the system will be complete by the middle of the next quarter. The delay has been in the precision machining of mounting platco for mounting the components. 


\section{SECTION VI}

\section{TASK 9-FUEL FABRICATION}

\subsection{PURPOSE}

The purpose of Task 9 is to procure fuel rods and associated core components for SEFOR. Fabrication of the hexagonal fuel channel and all of its internal components are a part of this task, as well as the instrumented fuel assembly fabrication.

\subsection{PAST ACCOMPLISHMENTS}

Following a number of rejections of both fuel pellets and fuel rods, GE released fuel production to the vendor, Nuclear Fuel Services Company (NFS).

Fabrication of fuel hardware and instrument fuel assemblies continued during the preceding quarter. Fabrication of channels neared completion.

\subsection{CURRENT RESULTS}

\subsubsection{Pellet Production}

All of the third master mix has been coprecipitated, and the fourth master mix was prepared. The fourth master mix will complete the fuel order except for the "guinea. pig" rods which have a $34 \%$ higher plutonium enrichment than the regular fuel. All NFS quality control results show the pellets to meet the specification.

\subsubsection{Second Phase Investigations}

Pellet batch 609 (approximately $125 \mathrm{~kg}$ of material) has been quarantined by NFS pending resolution of apparent impurity particles (or possible second phase) in the fuel oxide matrix. The apparent particle content is less thau the specification limit of $5 \%$ second phase, and NFS has determined that the pellet batch meets specification in all respects, including impurities and plutonium homogenity. The measurement for second phase is performed by estimating the area covered by the second phase from observations through an optical microscope. Thus far, with the possible exception of batch 609 , all pellet samples have exhibited no second phase in excess of the $5 \%$ specification. NFS has agreed to meet the $5 \%$ second phase limitation, as determined by optical microscopy with mixed oxide mounts, both in the as polished and etched state of preparation. As the quarter ended, these inclusions were being investigated at $\mathrm{GE}$ by means of the electron microprobe analyzer.

Several techniques were employed during preproduction evaluation to identify particles which were observed in those pellets. These methods included preferential etching, microhardness measurements, alpha autoradiography, and x-ray diffraction. These methods of investigation yielded uncertain results; with possible identifications ranging from a $\mathrm{Pu}-\mathrm{U}$ ceramic to iron. Optical microscopy and microprobe examinations are considered the only certain methods of analysis. Results of investigations by these methods on production pellet samples are described below.

\subsection{Optical Microscopy}

Visible "shiny particles" were examined in the unetched samples of lots 601 to 612. Most of the particles were very minute and randomly dispersed. At $250 \times$ magnification, many of these particles looked to be pin head size, but the average size was measured to be about $1 \mathrm{mil}$ by $1 \mathrm{mil}$.

The following tabulation lists the number of particles found in a total surface $250 \times$ scan of one unetched specimen from each pellet batch from 601 to 612 . 


\section{Pellet Batch}

No. of Particles Found

$\begin{array}{ll}601 & 46 \\ 602 & 63 \\ 603 & 43 \\ 604 & 10 \\ 605 & 11 \\ 606 & 43 \\ 607 & 19 \\ 608 & 33 \\ 609 & 51 \\ 610 & 26 \\ 611 & 31 \\ 612 & 34\end{array}$

With an average particle size of $1 \mathrm{mil}$ by $1 \mathrm{mil}$, the average area covered by the particles is less than $0.01 \%$ of the crosssectional pellet surface area. Thus, from observations on hand, the conclusion was reached that the quantity of the second phase was within the specifications and not of magnitude to warrant rejection of these batches.

\subsection{Electron-Microprobe Studies}

Work completed on a pellet from batch 609 shows that the above-mentioned shiny particles are mainly $\mathrm{Fe}, \mathrm{Ni}$, and $\mathrm{Cr}$. The quantitative ratios of these materials suggest that these inclusions are pieces of steel, probably the result of contamination during powder screening prior to pressing. As the total amount of impurity is less than that designated in the specification. and determined by chemical analysis, the presence of these inclusions cannot be made a basis on which pellets can be rejected. If one were to assume that the 0.001 -inch "shiny second phase" particles are composed of $\mathrm{Fe}$ and are dispersed uniformly throughout the pellets 100 particles (largest count of particles in any one cross section was 63) for each 0.001 -inch-thick cross section, the total content in the pellets would not exceed 100 parts per million. The specification allows 2500 parts per million of total impurities, and in all cases of NFS pel- lets this condition was met. Calculations, assuming the particles to be nickel or chromium, yield similar conclusions. Additional work on other apparent impurity particles (or second phase) in this pellet from batch 609 is under way.

A literature survey was made in regard to iron impurities in oxide fuels and their influence upon fuel performance.

The effect of impurities on fuel behavior at high burnup was investigated at the Westinghouse-Bettis Plant during the testing of plate-type element developed for use in PWR Core 2 Seed 1. ${ }^{(1)}$ Iron additions of 0.5 and $1 \mathrm{wt} \%$ were made to $96 \% \mathrm{TD}$, 40 -mil-thick fuel wafers of $\mathrm{ZrO}_{2}-36.5 \mathrm{wt} \%$ $\mathrm{UO}_{2}$ composition and irradiated to burnups to $55,000 \mathrm{MWd} / \mathrm{Te}$ in pressurized water loops, which is a factor of approximately 20 higher than maximum planned SEFOR fuel exposure. Center temperatures in these thin swelling or fission gas release plates were estimated at $1200^{\circ} \mathrm{C}$. No differences were noted between these samples and specimens that did not have the iron additive. The absence of detrlutental swelling in these plate elements implies that in this concentration at least, inert impurities do not impair element operation or lifetime.

\subsection{Pellet Physical Condition}

The average pellet rejection rate at NFS because of surface cracks and chips is 10 to $15 \%$ of those processed. The fuel specification allows surface cracks 0.003 inch or less wide and surface pits no more than 0.030 inch in diameter, provided that no more than $5 \%$ of the cylindrical surface or $10 \%$ of either end surface is missing because of chips, cracks, and pits combined. These limits were based on standards used in commercial $\mathrm{UO}_{2}$ pellet fabrication.

1 B. Rubin, B. Bermon, M. Bleiberg, "The Irradiation of $\mathrm{ZrO}_{2}-\mathrm{UO}_{2}$ Fuels, "WAPD-264,
(October 1962). 
NFS made considerable effort to improve the pellet appearance by adjustment of fabrication conditions using small test runs. Because this proved difficult to accomplish, NFS has been forced to grade the pellets prior to loading, rejecting those which exceeded the above-mentioned specification limits. The grading is based on general appearance, and it is performed by NFS operators who received instructions and training on the job. The results of their selection was observed and checked regularly by NFS quality control personnel, NFS supervisory personnel, and GE on-site inspectors and other personnel making periodic visits there.

Testing was performed at NFS to determine the effect of pellet cracking. Five pellets were selected which appeared to be the worst acceptable pellets in that particular batch. All pellets were intentionally dropped from a height of 2-1/2 feet onto a metal surface. One pellet broke into two pieces on the sixth drop. A second pellet broke into two pieces on the first drop. The remaining pellets were dropped more than six times with no breaking and with no visible damage. It was judged that handling the pellets prior to reactor loading constitutes less abuse than the above tests and that at the time of reactor startup, pellet integrity will be maintained to the level determined at the time of loading. In past experience with both urania and mixed oxide fuels, cracking of the fabricated pellets has never been shown to be detrimental to fuel element performance.

\subsection{Pellet Volati.ile Content}

Volatile content tests of preproduction pellets (first master mix) in June-July 1967 indicated that possible surface contamination dictates that the sample should be properly chosen to be representative of the entire pellet diameter. The volatile content of a one-quarter pellct sample was measured to be well below the specification limit of $50 \mu \ell / g m$.
Initial tests of volatile content conducted by an independent laboratory with a production pellet sample from batch 603 (second master mix) showed that the pellet sample did not meet the total gas release (excluding moisture) specification. In six separate analyses conducted at this laboratory, there is a factor of 10 difference between the highest and lowest gas release results, the lowest being approximately twice the specification limit. Since this variation and the sample preparation raised some doubt concerning the validity of the results, additional identical pellet samples were prepared by GE-VNC and distributed to four independent laboratories. Results of these tests and visits to these laboratories and to NFS by GE analytical chemists indicated the NFS and Oak Ridge National Laboratory (ORNL) have equipment and procedures which should yield reliable results. ORNL results showed that pellet total gas release to be approximately $70 \mu \ell / \mathrm{gm}$, while NFS results have always shown total gas to be in the range 10 to $25 \mu \mathrm{l} / \mathrm{gm}$. Since the pellet sample preparation is judged to be critical in obtaining comparable results, a series of tests are being conducted at ORNL and NFS on identical samples prepared by NFS. The purpose of these tests is to show the degree of correspondence between the two systems in measurements of low gas, nominal (specification limit) gas, and high gas content, Preparations for these tests were being made as the quarter ended.

\subsubsection{Fuel Rod Production}

Loading and welding of fuel rods ceased on January 9, 1968, pending resolution of the total gas content in the fuel pellets. A summary of the welded rods is shown below:

280 rods welded

104 rods shipped to SEFOR site

76 rods ready for shipment to SEFOR 100 rods rejected (approximately 50\% of these are leakers; must of lie uthers were rejected because of various weld deficiencies) 
Initial investigation of two rods which were found to have a high helium leak rate showed that the leak path was in the end plugs and not in the weld. Most of the leakers have a relatively low leak rate, thus determination of the location of the leak is not possible with the equipment available at NFS. Since dis covery of the end plug leaks, all end plugs are helium leak-checked by NFS prior to welding. As a result of the high incidence of leaking rods, it was decided to add a helium leakcheck to the fuel rod receiving inspection at SEFOR. Equipment procurement was initiated as the quarter ended.

Rod repair procedures, involving cutting the rod at the weld and rewelding a new end plug, are being studied. To meet the rod length specification, it may be necessary to leave some weld metal on the rod when cutting off the end plug. NFS has submitted such repair welds to $G E$ for examination, and preliminary study of weld metallography has shown that these repair welds are satisfactory.

Several rods have shown an alpha particle count higher than the specification limit, the high count rate being associated with the weld area. A slag-like particle showing a high count was observed under $40 \times$ magnification at the tail-off of these welds. Although it was felt that this particle floated only on the surface of the weld as a slag, it was deemed advisable to section through this area to determine the possibility of finding similar particles leading from the inner surface of the tube; through the weld zone, to the outer surface. Metallography performed at three different levels through the area of the particle revealed no inclusions at any point in the weld.

It is concluded that these particles are an accumulation of minute fuel particles that collect as the weld progresses around the tube, and are finally deposited at the solidified end of the weld tail-off. Further tests show that this particle is easily dis- lodged by light application of 600-grit abrasive paper. The incidence of high alpha activity on the welded rods decreased as the vendor performed more frequent cleaning of the fuel rod end prior to welding and cleaning of the welding chamber.

Receiving inspection at SEFOR of the 104 delivered rods showed that the rods met the external dimensional specification except that the electron beam weld at the center spacer was approximately 0.001 inch ton high. NFS sent personnel to the SEFOR site to remove the excess material by polishing.

\subsubsection{Fuel Hardware Fabrication.}

Fuel hardware fabrication is in progress. The hexagon tubing for the tightener sleeve was received. The as-fabricated hardness of the tubes were found to exceed specification, but because of the relatively low SEFOR operating temperatures, it was judged that the hardness would cause no significant warping and the tuhes were released for machining; $95 \%$ of the tubes were machined during the quarter. The external springs were fabricated and heat treated. The first prototype internal springs were undergoing fabrication development. Machining of the spiders was completed. 'The final batch of fins was received.

Work was started on the tooling for the hydro forming of the tightener rod.

All internals for the extension rods were completed. The upper and lower reflectors were machined and the $\mathrm{BeO}$ rods and pellets were received. Machining was completed on $75 \%$ of the lower end plugs. The tube forming vendor submitted preproduction samples which.were found to be oversized. Although the vendor subsequently reworked his dies, the resulting samples were still oversized. Because further reworking of the dies would have resulted in a further delay, it 
was decided to direct the vendor to proceed with the forming of the tubes and to swage all oversized tubes.

All parts for the foil-holder rod were placed on order.

The fuel channels were completed and have arrived at the SEFOR site.

Nuclear Fuels Service has completed fabrication of the springs, external tubing, and top and bottom end plugs for the surveillance rods. The extension rod for the surveillance rod was completed in the GE shop.

\subsubsection{Instrumented Fuel Assemblies}

The fabrication of tungsten rhenium fuel thermocouples continues to be a delay in the overall instrumented fuel assembly fabrication effort. Several thermocouples using 0.005 -inch-diameter wires were successfully made and tested but this was accomplished only after a great deal of extra unplanned effort had been applied.

To prevent tungsten-rhenium sheath failure, which occurred during inttlal fuel therrnocouple fabrication, the bending jig was modified to distribute the stress over the complete outside surface of the sheath during the bending operation. A fabrication shnp suggestion of crimping rather than brazing for the connection of the tungsten-rhenium thermocouple wire to the compensated lead wire (using the nickel transition sleeve) was evaluated by analysis and thermal cycle test. It was concluded not to use this method and the brazed connection continues to. be the final design.

A successful method of fabricating the wire transition by using a spiral wrap of nickel ribbon in place of the solid nickel sleeve has been developed. It appears that this recent development work has overcome the two large problem areas in fuel thermocouple fabrication: (1) breaking of the $\mathrm{W} / \mathrm{Re}$ at its braze point into the nickel sleeve, and (2) splitting of the probe sheath as the final bend was made.

The VNC-IPO machine shop continues to machine parts for the instrumented fuel assemblies.

The deliveries of the formed tubes for the extension rods and tightener rods still continue to be limiting items. The latest promises for completed rods and sleeves are:

$\begin{array}{ll}\text { Extension Rods } & \text { February 23, 1968 } \\ \text { Tightener Rods } & \text { March 22, 1968 } \\ \text { Tightener Sleeves } & \text { February 16, 1968 }\end{array}$

All of the clad tubing has been received and ultrasonically inspected. An ultrasonic standard was fabricated with defects in the outside diameter and irside diameter equiva:lent to 5,10 , and $15 \%$ of the wall thickness. No defects in the tubing greater than, or equal to, $10 \%$ were found upon inspection.

Fabrication of fuel rod hardware was completed; cleaning and passivation were performed.

Insulator pellets were received from the Fuel and Material Development Shop to be chipped. The pellets will be inspected and acceptance or rejection will be based on the fuel pellet chip specifications.

Inspection and drilling of NFS-fabricated pellets has been initiated; early inspection indicates several pellets with circumferential cracks. 'Slotting of the fuel pellets has not yet been attempted, but initial drilling appears to present no cracking or chipping problem. Operation of all equipment is judged to be satisfactory . 
Trips were made to Oliver Johnson Machine Shop in San Jose, Statham Instrument Co. in Oxnard, Calif., and Aeroquip Marman Division in Los Angeles to deal with problems arising during vendor IFA parts fabrication effort.

Conoseal flanges from Aeroquip are slipping schedule. The latest delivery promise for these flanges is February 29, 1968, and delivery is being expedited. Further slippage of these flanges will jeopardize delivery of the completed fuel connectors to the SEFOR site by May 1, 1968.

GE-APO is continuing to work with Statham Instrument Co. to resolve electrical connector design problems. Electrical connector drawings were revised to comply with approved vendor suggestions.

The present estimated delivery date of the first IFA to SEFOR is June 15, 1968. This is in advance of the date required for reactor power operation to give the reactor operations group time for familiarization with handling. The delivery date shown above is contingent upon (1) the $\mathrm{T} / \mathrm{C}$ fabrication procedure now being used by the IPO Shops being a "repeatable" process; (2) sufficient fuel for the first IFA being received almost immediately; (3) no slippage occurring on certain outside vendor items such as Conoseal flanges; and (4) onschedule delivery of the upper tightener rods.

\section{SECTION VII}

\section{TASK 10-STARTUP TESTING}

\subsection{TASK 10.3-WET CRITICAL TESTING}

\subsubsection{Purpose}

The purpose of Task 10 is to investigate the startup characteristics of a $\mathrm{PuO}_{2}-\mathrm{UO}_{2}$ fueled fast reactor and compare the experimental results to the theoretical calculations. The wet critical tests comprise Task 10.3, and Task 10.4 includes tho initial approach to full power.

\subsubsection{Past Performance}

Work was begun to identify and procure special experimental equipment which includes activation foil materials, foil holder rods, reactor noise analysis equipment and special startup instrumentation, and gamma source and detection equipment for fuel transmission gamma scan.

\subsubsection{Current Results}

\subsubsection{Reactor Noise Analysis Equipment}

Frequency response and drift tests were performed which demonstrated that the SEFOR transient amplifier in conjunction with an appropriate input filter circuit (see Fourteenth Quar terly, GEAP 5561) would be adequate for the planned noise measurements.

However, the amplifier gain and expected ion chamber currents are so low that an additional voltage amplifier will be needed to provide a signal level high enough for recording.

\subsubsection{Reactor Vessel Material Surveillance Specimens}

The reactor vessel material surveillance specimens were received. As noted in the Task 9 section of this report, the surveillance specimen holder rods have been placed on order and the extension rods have been completed. 


\section{SECTION VIII}

\section{SEFOR TRAINING}

\subsection{PURPOSE}

The purpose of the SEFOR training is to recruit and train the various technical, operator and maintenance personmel required for the operation of the SEFOR facility, accomplishment of the SEFOR experimental program, and accomplishment of the planning, procurement, and testing functions related to the startup of a new facility.

\subsection{PAST ACCOMPLISHMENTS}

The SEFOR training program was initiated. Personnel hired totaled 22. Preparation of the preoperation test procedures for each system, corrective procedures, and standard operating procedures was initiated. Initial results of the preoperation environmental survey were reported to the AEC Division of Compliance.

\subsection{CURRENT RESULTS}

The formalized portion of the SEFOR training program in California was completed and all personnel transferred to the SEFOR site. Training was continued by work assignments and preoperational tests at the site.

The first shipment of SEFOR fuel, 104 rods, was received and mechanical inspection and measurements completed. The writing of preoperational tests and standard operating and corrective procedures was continued. Recruiting of personnel was continued with 29 of the total of 40 personnel hired. All key positions have been filled and all reactor operators recruited except one. The preoperational environmental survey program was continued.

\section{SECTION IX}

\section{PLANT CONSTRUCTION}

\subsection{MECHANICAL DEPARTMENT}

\subsubsection{System Design and Equipment Procurement}

The Mechanical Department system design is completed. Work during the past quarter has consisted of minor drawing changes for corrections and updating for as-built conditions.

On December 15, 1967, the drawings of Nitrogen Cooling Piping, Sheet 1 and Sheet 2 , were revised and issued. The issue covered revisions to the halogen leak detector sampling piping to accommodate the Generăl Electric Company halogen leak detector.

The piping and instrument diagrams are being updated to agree with as-built conditions and field changes.

All items of mechanical equipment have been purchased.

\subsubsection{Rupture Discs and Relief Valves}

"Revised manufacturer's drawings of the rupture disc and relief valve assemblies were received, reviewed, and returned to 
the manufacturer. All relief valves and rupture disc assemblies are scheduled for shipment on or before February 7, 1968.

\subsection{ELECTRICAL DEPARTMENT}

\subsubsection{System Design and Equipment Procurement}

The release of the electrical system wiring drawings for construction was essentially completed during this report period. Several miscellaneous detail drawings remain and are currently being completed.

A complete recheck of all required cable quantities and penetration hardware is currently under way. The recheck is a normal function which is done upon the completion of the design.

\subsubsection{Drawing Release Schedule}

The electrical drawing release schedule was revised as of January 20, 1968, showing completion dates for the annunciator schematics, together with other minor changes.

\subsection{CONSTRUCTION MANAGEMENT}

\subsubsection{General Work Contract}

Martin K. Eby Construction, Inc. again returned to the site on December 18, 1967. The contractor completed the closure of the refueling cell construction opening.

\section{3 .2 Insulation}

Johns-Mansville Sales Corporation has essentially completed insulation work on the air blast coolers and on sodium piping in that area. Insulation work in the penthouse secondary sodium rooms and pipe tunnel is approximately $95 \%$ complete at this time. The mirror insulation and sodium piping out of the reactor is approximately $80 \%$ complete.

\subsubsection{Reactor Erection}

Austin Building has installed the reactor vessel shroud, reflector guide structure and the bottom shield plug. Work continues on the installation of shield plates and liner segments.

\subsubsection{Piping}

Cherne Contracting Corporation has completed the welding and radiography of MCS and ACS piping systems. Other systems completed during this period include the radioactive liquid radwaste system, service water system, and the diesel fuel oil system. Work has continued on the erection, welding, and radiography of the SSS piping, gaseous radwaste, nitrogen cooling, breathing air, Freon, and argon piping systems. Work has also continued on the reactor building air conditioning system duct work and has been completed as far as possible at this time.

\subsubsection{Electrical Work}

Commonwealth Electric Company completed the installation of MI cable at the containment vessel penetration area and also completed the liquid radwaste system with the exception of the radiation monitoring interlocks for the transfer and discharge pumps. The contractor set into operation the instrument and breathing air compressor. Commonwealth Electric also completed the installation of the nitrogen cell penetration plugs. 'The installation of thermocouples on the reactor guide structure, lower shield plug, and the irradiated fuel storage tank is completed. The contractor also continues to work on the installation of Calrod heaters and equipment for the sodium trace heating system and continues to pull and terminate cable throughout the plant. Commonwealth Electric has started the work on the main and auxiliary air blast coolers and pump power supplies. 


\section{CONTRIBUTORS}

The following people contributed to the work performed on the SEFOR Research and Development Program during the quarter ending January 31, 1967.

Task 1-Planning the Experimental Program

L. Noble

C. Wilkinson

A. Reynolds

Task 5-Steady -State and Transient Characteristics of the Core Assembly
J. Cochran
C. Russell
E. Polomik
R. Williams

Task 6-Reactivity Controls Required for Experimentation
C. Craig
J. Krankota
E. McKeehan
M. Wittry
W. Margetanski

Task 7-Fuel Handling
G. Brynsvold
A. Steamer
L. Franckx

\section{Task 8-Corc Design}
K. Hikido
ii, Olich
R. Meyer
A. Reynolds

Task 3-Fuel Development

P. Novak
Task 4-Special Instrumentation
L. Franckx
L. Wimpee
C. Von Damm
M. Wittry.

Task 9-Fuel Fabrication
E. Craig
R. Miller
R. Eymann
E. Olich
D. Ikeuye
R. Pope
M. Johnson
R. Wallace
T. Lannin
F. Young
R. Hoffmann
P. Novak
R. Asamoto
C. Spalaris

Plant Construction
G. Billuris
J. Ehlers
S. Carlson*
C. O. Nelson
C. M. Chiapetta*
M. Trammel
J. A. Donald*

SEFOR Operations
J. Arterburn
D. Cary

R. Becker

Other Contributors
K. Cohen
J. Hoyt
G. Collins
M. McNelly
J. Forster
R. Pflasterer
P. Greebler
B. Wolfe
K. Horst
E. Zebroski

* Sargent and Lundy 


\section{DISTRIBUTION}

Division of Technical Information Extension U.S. Atomic Energy Commission P.O. Box 62

Oak Ridge, Tennessee

Director

Research and Development Division

U.S. Atomic Energy Commission

Richland Operations Office

P.O. Box 550

Richland, Washington 99352

Mr. G. Vendryes

Cen Saclay

Boite Postale 2

Gif-Sur-Yvette (S et O) France

Dott, Ing. F. Perantoni

CNEN

Viz Mazzini 2

Bologna, Italy

Mr. E.E. Kintner, Chief

Fuel Fabrication Branch

DRD\& $T$, USAEC

Washington, D.C. 20545

Mr. W. O. Turner,

Chairman of Board

Louisiana Power and Light Company

142 Delaronde Street

New Orleans, Louisiana

Mr. R.C. Green, President

10700 East 50 Highway

Kansas Clty, Missouri

Mr. L.J. Cucullu, Vice President

New Orleans Public Service Inc.

317 Baronne Street

New Orleans, Louisiana

Mr. B.S. Jeffrey, President

Kansas Power and Light Company

808 Kansas Avenue

Topeka, Kansas

Mr. J. Robert Welsh,

Chairman of the Board

Southwestern Electric Power Company

P.O. Box 1106

Shreveport, Louisiana

Power Reactor Development Company

1191 First Street

Detroit, Michigan 48226

Mr. E. R. Astley

Project Manager

FFTF Project

Pacific Northwest Laboratory

Richland, Washington 99352

Mr. J.M. Simmons, Chief

Fuels and Materials Bianch

DRD\& T, USAEC

Washington, D.C. 20545
3

Mr. R.S. Boyd

1

Assistant Director for Reactor Projects

Division of Reactor Licensing

DRD\& T, USAEC

Washington, D.C. 20545

1

Director

Los Alamos Scientific Laboratory

Los Alamos, New Mexico 87544

Dr. John C. Wondhouse

10

1 Guest Lane

Wilmington, Delaware 19809

Senior Representative

U.S. Mission to EURATOM Communities

c/o U.S. Embassy

4 Brussels, Belgium

General Directorate

Research and Training

10

$151-53$ Rue Belliard

Brussels, Belgium

Attn: A. DeStordeur

1 Mr. F.H. Coughlin, President

Central Louisiana Electric Co., Inc.

Pineville Louisiana

Mr. John Stewart, President

The Central Kansas Power Company

1111 East 11th Street

Hays, Kansas

Mr. Reeves Ritchie, President

1

Arkansas Power and Light Company

Ninth and Louisiana Street

Little Rock, Arkansas

Mr. J.T. Jones, President

1

The Empire District Electric Co.

602 Joplin Street

Joplin, Missouri

Mr. Harold E. Mortimer

Assistant to Chairman of the Board

Gulf States Utilities Company

P.O. Box 2951

Beaumont, Texas

Mr. C.F. Edwards, Vice President

1

Western Power and Gas Company, Inc.

P.O. Box 170

Great Bend, Kansas

Gesellschaft fūr Kernforschung m.b.H. 10

Projekt Schneller Bruter

75) Karlsruhe, Germany Postiach 947

Mr. A. Amorosi, Director

LMFBR Program Office

Argonne National Laboratory

Süutli Cass Avenue

Argonne, Ililino1s 60439
1 


\section{DISTRIBUTION (Continued)}

Mr. J . Crawford

Asst. Director for Plant Engineering DRD\& $T$, USAEC

Washington, D.C. 20545

Mr. M.A. Rosen

Asst. Director for Program Analysis

DRD\& $T$, USAEC

Washington, D.C. 20545

Brookhaven National Laboratory

Associated Universities, Inc.

Upton, Long Island, New York, 11973

Attn: Dr. C.H. Raseman

Mr. J.J. Morabito

Project Manager

Special Projects Branch

DRD\& T, USAEC

Washington, D.C. 20545

Mr. G.W. Evans, President

Kansas Gas and Electric Company

201 North Market Street

Wichita, Kansas

Mr. L.F.C. Reichle

Ebasco Services, Inc.

2 Rector Street

New York 6, New York

Mr. R.B. Wilson, President

Mississippi Power and Light Company

Electric Building

Jackson, Mississippi

Mr. Ray W. Call, President

Missouri Utilities Company

400 Broadway

Cape Girardeau, Missouri

Mr. D.S. Kennedy, President

Oklahoma Gas and Electric Company

321 North Harvey Street

Oklahoma City, Oklahoma

Mr. D.J. Tuepker, President

Yublic Service Company of Oklahoma 600 South Main Street

Tulsa, Oklahoma

Dr. G.W. Wensch

Chief, Liquid Metal Project Branch

DRD\& $T$

U.S. Atomic Energy Commission

Washington, D.C. 20545

Dr. J.A. Lieberman

Asst. Director for Nuclear Safety

DRD\& $T$

Washington, D.C. 20545

Director, Contracts Division

U.S. Atomic Energy Commission

San Francisco Operations Office

2111 Bancroft Way

Berkeley, California 94704
2 F.W. Thalgott

Associate Director,

Idaho Division

Argonne National Laboratory

Box 1096

2 Idaho Falls, Idaho 83401

Director, Argonne National Laboratory 2 9800 South Cass Avenue

Argonne, Illinois 60439

1

Attn: S. Lawrowski

Dr. I. Zartman, Chief

Reactor Pnysics Branch

DRD\& $\mathrm{T}$, USAEC

1 Washington, D.C. 20545

Mr. C.C. Czeschin, President

Arkansas-Missouri Power Company

104 South Fifth Street

Blytheville, Arkansas

1

Mr. T. Flynn

Ebasco Services, Inc.

2 Rector Street

New York City 6, N.Y.

1

USAEC

Office of RDT Site Representative

310 DeGuigne Drive

Synnyvale, Calif. 94086

1 Attn: C.R. Eisenschmidt, Jr.

Directón

Liquid Metals Information Center

P.O. Box 309

1. Canoga Park, Callf. 91305

Mr. S. Golan, Project. Manager 1000 MWe LMFBR Follow-On Study Atomics International

1 P.O. Bóx 309

Canoga Park, California 91304

Mr. M,W, Croft, Project Manager

$1000 \mathrm{MWe}$ LMFBR Follow-Ón Study

1 The Babcock and Wilcox Company

5061 Fort Avenuc

P.O. Box 1260

Lynchburg, Virginia 24505

1

Dr. W.P. Staker, Project Manager 1000 Mwe LMFBR Follow-On Study Combustion Engineering, Inc.

P. 0 . Box 500

Windsor, Connecticut 06095

1 Mr. C.A. Anderson, Project Manager

1000 MWe LMFBR Follow-On Study

Westinghouse Electric Corporation

Advanced Reactors Division

Waltz Mill Site

$2 \quad$ P.O. Box 158

Madison, Pennsylvania 15663 


\section{DISTRIBUTION (Continued)}

Mr. L.W. Fromm, Manager

1000 MWe LMFBR Follow-On Study Project

Building 208

Argonne National Laboratory

9800 South Cass Avenue

Argonne, Illinois 60439
2

USAEC Scientific Representative
United States Embassy

London, England 